Виктория Пичугина

ORCID: 0000-0002-1195-725X

Институт стратегии развития образования Российской академии образования

Москва, Россия

\title{
ЦЕРКОВЬ VS ТЕАТР В ПОЗДНЕЙ АНТИЧНОСТИ: НАСТАВЛЕНИЕ ПРОПОВЕДЬЮ ИЛИ НАСТАВЛЕНИЕ ЗРЕЛИЩЕМ? ${ }^{1}$
}

\author{
https://doi.org/10.34739/clit.2020.14.02
}

\section{CHURCH VS THEATER IN LATER ANTIQUITY: INSTRUCTION BY PREACHING OR BY PERFORMANCE?}

The article analyzes the pedagogical competition between the theater with its poetic instructions and the church with its instructive rituals, preaching and liturgy in Late Antiquity. Within the framework of the Christian pedagogical tradition, there has been a change in meanings for existing terminology regarding theater. The term "actor" began to mean a hypocritical person pretending to be righteous, and the "theater" from a school for the worthy turned into a school for the obscene. This made it possible to affirm the new aesthetics of the ritual and secure for the church, and not for the theater, the right to give instruction as a strengthening of the correct understanding of what is due.

Keywords: ancient pedagogical culture, theater in Late Antiquity, Christian pedagogical tradition, instruction by preaching, instruction by performance

Поздняя Античность для современных исследователей является периодом, интересным для изучения острых противоречий в общественных институтах и сферах жизни общества. Особой областью исследовательского интереса является существовавшее в Поздней Античности противоречие между церковью с ее ритуалами, проповедями и литургией и театром с его ритуалами и драматическими конвенциями, завершившееся тем, что церковь

\footnotetext{
${ }^{1}$ Работа выполнена при финансовой поддержке РФФИ, в рамках проекта (№ 19-013оооо4) «Эволюция пространства образования и пространства знания в Поздней Античности».
} 
в итоге стала главным наследником античного перформативного мира. Если вспомнить обязательные элементы театрального действия - ограниченный промежуток времени действия, определенный набор исполнителей (в т.ч. хор) и аудитория, собравшаяся в конкретном месте и по конкретному случаю, - то между церковью и театром не так просто провести границу. В простоте этого вывода скрыта логическая ловушка. С одной стороны, целью речевых актов как в языческом театре, так и в христианской церкви выступает не столько передача информации, сколько достижение некой цели, а ответственность за грамотную организацию в большей мере несет один человек - священник или драматург-режиссёр соответственно: проповедь не проповедь, если у нее нет зрителя-слушателя, который наставляется, говоря в ответ «аминь», но и драма не драма, если у нее тоже нет зрителяслушателя, который наставляется и также дает свой ответ. С другой стороны, история театра не является непрерывной линией, идущей от древнегреческих праздников в честь Диониса через период становления христианства, а затем через средневековый театр к современной драме. Движение «от античности к современности» не обещает нам гладкой дороги с мостовыми переходами на тех участках, где мы особенно хотим найти преемственность в сферах образования и культуры. Если о проповеди как функции средневекового театра написано немало ${ }^{2}$, то о театральности как функции позднеантичного религиозного ритуала, включившего в себя проповедь, много меньше. В рамках данной статьи речь пойдет о педагогической конкуренции между театром и церковью в Поздней Античности, без опоры на популярную среди ряда исследователей гипотезу о том, что современный театр вышел из христианского ритуала и подобная «эволюция» «должна была произойти в греческой церкви в течение первого тысячелетия»3.

\section{Театр в религиозном пространстве Поздней Античности: школа достойных или школа непристойных?}

Отношение к театру в Поздней Античности во многом оказалось связанным с христианской педагогической традицией, которая прошла долгий путь становления. Зародившись в недрах языческой культуры, новая религия переняла много «черт, символов,

2 См. напр. обзор: 3.А. Лурье, Лютеранская проповедь и драматургия: опыт типологических параллелей, „Религия. Церковь. Общество” 2015, № 4, с. 180-187.

3 W. Puchner, Greek Theatre Between Antiquity and Independence: A History of Reinvention from the Third Century b. c. to 1830, Cambridge 2017, p. 53. 
художественных стилей, изображений и даже языка языческого происхождения», но публичной «театральности» города предпочла индивидуальное духовное созерцание ${ }^{4}$. Этому способствовала реализация множества стратегий, одни из которых были более, а другие менее успешны. Остановимся на стратегии сохранения существовавшей терминологии, касающейся театра и театральности, но придания терминам иного значения. Эта стратегия имела непосредственное отношение к педагогическому противостоянию театра и церкви как пространств, способных наставить человека в правильном понимании событий через демонстрацию одобряемых образцов мышления и поведения, и нашли отражение в сочинениях Отцов Церкви.

Античная театральная рамка имела как физическое (театр как священное пространство), так и концептуальное измерение («рамка сознания»)5. Задолго до принятия христианства как официальной религии Квинтилиан закрепил возможность создания некоего подобия театрального пространства в любых сферах, намекая на приоритетность концептуального измерения над физическим. Хороший оратор, по мнению Квинтилиана, всегда в конце своей речи, например перед судьями, должен был «наиболее трогать умы» и «оканчивать тем, чем древние трагедии и комедии заключались на театре: Рукоплещите» (Quint. Inst. VI.52) ${ }^{6}$. Христианские наставники были против того, чтобы кто-то «трогал умы» театральными способами, да еще и мог повелевать слушающим рукоплескать. На то было достаточно причин, одна из которых, вероятно, связана с тем, что в существующих описаниях жизни Иисуса нет никаких указаний на театр, несмотря на то что Ирод Великий построил театры в Иерусалиме и других городах:

Иисус никогда не ходит в театр и никогда не встречает актеров или актрис. Для читателя первого века нашей эры отсутствие такого популярного римского культурного учреждения означало бы (среди прочего), что Иисус был наблюдательным евреем, который избегал языческих спектаклей 7 .

4 Ibidem, p. 54.

5 M. Revermann, Introduction, in Cultural History and the Theatres of Antiquity, London-New York 2017, p. 20.

${ }_{6}$ Марка Фабия Квинтилиана двенадцать книг Риторических наставлений, СанктПетербург 1834, часть I, http://ancientrome.ru/antlitr/t.htm?a=1327752826, [дата доступа: 27.09.2019].

7 A.W. White, The Artifice of Eternity: A Study of Liturgical and Theatrical Practices in Byzantinum: Ph.D. diss., University of Maryland, 2006, p. 46. 
Иосиф Флавий так поясняет это:

(...) он [Ирод] (...) построил в Иерусалиме театр, равно как на равнине огромнейший амфитеатр, которых роскошь бросалась всем в глаза, но которые отнюдь не соответствовали мировоззрению иудеев, ибо иудеи были непривычны к такого рода зрелищам (Jos. Ant. XV.8.)8.

После появления Септуагинты во втором веке до нашей эры культурная реакция против театра как формы искусства дополнилась теологической реакцией, когда религиозное притворство стало связываться с театральным действием, а слово «актер» - с лицемером, то есть человеком, желающим притвориться праведником.

Со времен Августина, уделившего в $O$ граде Божьем внимание истории создания Cептуагинты, в консервативных церковных кругах к театру относились с недоверием, а некоторое сходство, например, литургии и театральной постановки, игнорировалось. В O граде Божем Августин выделяет в пространстве города секторы, помогающие или мешающие образованию и укреплению в вере, одним из которых является театр. По мнению Августина, театральная зрелищность опасна для верующего, а воспитательное влияние поэзии - сомнительно. Для того чтобы доказать это, он своеобразно обращается к истории театра:

Ибо с самого начала сценические игры в Риме были установлены по определению понтификов во время моровой язвы. Кто же после этого не придет к мысли, что в образе жизни своей он должен скорее следовать тому, что представляется на зрелищах, установленных по божественному приговору, чем тому, что пишется в законах, учрежденных человеческой мудростью? (August. De civ. D. VIII)9.

В Исповеди Августин вспоминает о том, как, будучи школяром, читал Теренция, и указывает на фрагмент его комедии Евнух (Ter. Eu. 583-591). Августину, вероятно, не нравится не столько похождения бога Юпитера как героя комедии, сколько вывод, который делает Теренций от лица смертного: «Ну, как не совершить того ж мне, человеку малому?»10 (Ter. Eu. 591). Филипп Бартон, анализируя Исповедь Августина, пишет следующее:

\footnotetext{
${ }^{8}$ Иосиф Флавий, Иудейские древности. Т.2. Кн. 13-20, О древности иудейского народа (Против Апиона), Москва 2002, с. 173.

9 Блаженный Августин, Творения в 4 m. Т.з. О Граде Божием. Книги I - XIII, СанктПетербург - Киев 1998, с. 60.

10 Теренций, Евнух, [в:] Комедии, Москва 1985, с. 234.
} 
Проблема заключается не в словах Теренция - позиция Августина по этому поводу ясна - а в системе образования, которая стремится учить языку и литературе без отсылки к морали. (...) поскольку Августин завоевывает репутацию смышленого школяра, он считает, что мир рукоплещет ему с криком euge euge (I. 13. 21). Это греческое восклицание («bravo!») в классической латыни наиболее часто встречается в комедии ${ }^{11}$.

Бартон указывает на то, что Исповедъ представляет собой уникальный педагогический нарратив, по жанру близкий к комедиям того же Теренция. Выражаясь словами Квинтилиана, Августин против того, что кто-то «трогал умы» театральными, а не религиозными способами, но сам не прочь намекнуть слушающим его: «Рукоплещите!».

Языческий театр был «школой на сцене»12, что не могли оставить без внимания хорошо знавшие античные трагедии и комедии Отцы Церкви. На то, что театр является особым образовательным пространством со своими законами и правилами, указал еще Аристофан, вложив в уста «отца трагедии» Эсхила следующие слова:

Зевс свидетель, все - правда! Но должен скрывать эти подлые язвы художник, / Не описывать в драмах, в театре толпе не показывать. Малых ребяток / Наставляет учитель добру и пути, а людей возмужавших - поэты. / О прекрасном должны мы всегда говорить (Ar. Ran. 1054-1057) ${ }^{13}$.

Аристофан подчеркнул, что в театре поэты выступали в роли наставников, а зрители - в роли учеников. Театр для него был школой для взрослых; школой достойных граждан, которые готовы внимать поэтическим наставлениям. С христианской точки зрения, здесь так же, как и в случае с термином «актер», была необходима трансформация значений. Взялся за нее Иоанн Златоуст, которому приписывают определение современного ему театра «как школы непристойных и нечестивых», поскольку аудитория в Поздней Античности предпочитала драмы о прелюбодеяниях и соблазнениях ${ }^{14}$. Предпочтение не означало, что традиционным наставлениям из трагедий не было место на сцене или они не

\footnotetext{
${ }^{11}$ P. Burton, Language in the Confessions of Augustine, New York 2007, p. 40.

12 В.К. Пичугина, Школа на сцене: уроки греческого театра $V$ в. до н.э., [в:] Исторические пути развития образования и педагогики, Москва 2015, с. 71-77. 13 Аристофан, Лягушки, [в:] Комедии. Фрагменты, Москва 2008, с. 680.

14 B. Leyerle, John Chrysostom's view oh the theater, in Theatrical Shows and Ascetic Lives: John Chrysostom's Attack on Spiritual Marriage, Berkeley 2001, p. 43.
} 
воспринимались зрителем. Просто доказательство безнравственности театра как некоего суммарного пространства мимов, гладиаторов, трагических актеров и т.д. было значимой частью аргументации в пользу утверждения новой ритуальной эстетики. Разрыв между театральной и христианской ритуальностью расширялся в текстах, но сужался на практике, поскольку драматические аспекты литургии, были закреплены самим же Иоанном Златоустом с использованием театральных приемов 15. Театральность была не только обязательным элементом многих зрелищных мероприятий, но и способом привлечения слушателей к мероприятиям религиозным. В одном из писем современник Иоанна Златоуста Святой Паммахий пишет о том, что в позднеантичном мире все будет просмотрено либо светской, либо религиозной аудиторией: «Вы даете спектакли для церкви; вы кандидат не по тщеславию на арене [амфитеатра], а для вечной похвалы» ${ }^{16}$.

\section{Изменение пространств образования и знания: от освещенной солнцем сцены к приглушенному свету в церкви}

Театры в городах Восточной Римской империи демонстрировали симбиоз трех ключевых элементов, что отражалось в:

(...) проявлении имперской и гражданской идеологии; демонстрации театрального мастерства; и всеобъемлющем богословии, поместившем эти зрелища в божественную иерархию, где приняли участие все римские граждане ${ }^{17}$.

Особенности помещения театра в «божественную иерархию» были не лишены педагогического умысла, поскольку христианские наставники не могли не признавать силу театральных механизмов как средств для привлечения аудитории и ее наставления. Наставления, идущие со сцены древнегреческого театра, отражали актуальные способы «педагогического воздействия» на аудиторию, частью которой, например, для Еврипида являлся Сократ. Диатриба, восходящая к сократической беседе, «и, позднее, проповедь складываются как жанры устного творчества, ведь и адресованы они были, прежде всего, широкой аудитории, и содержали в себе набор

\footnotetext{
${ }_{15}$ A.W. White, op. cit., p. 50-51.

${ }^{16}$ Цит. по: L.S. Lieber, Setting the Stage: The Theatricality of Jewish Aramaic Poetry from Late Antiquity, "The Jewish Quarterly Review" 2014, Vol. 104(4), p. 539-540.

${ }^{17}$ A.W. White, op. cit., p. 3.
} 
определенных средств и приемов, направленных именно на убеждение» ${ }^{18}$.

Отцы Церкви были хорошо образованными людыми и понимали, что с момента своего возникновения античный театр был одновременно светским и религиозным (=языческим) заведением. В своих текстах они его отвергали, клеймили как развращающее нравы развлечение, а потом использовали пластичность и открытость театральных механизмов воздействия на аудиторию, но уже для новой религии. Христианские наставники, как и языческие драматурги, тоже хотели, чтобы их слушали и слышали. «Хотя враждебное отношение церкви в первые века нашей эры действовало как решающий катализатор, процесс роспуска и смены перформативных жанров уже начался задолго до этого ${ }^{19}$. Античный театр является уникальным феноменом, который появился и сам подошел к концу. Задолго до появления христианства возникли радикальные изменения театральных форм (например, от любительского к профессиональному театру) и функций театра (например, от освещения политически актуальных вопросов в комедиях Аристофана до внутрисемейных конфликтов в комедиях Менандра), изменения политического управления и структур, обеспечивающих театральную институциональность (например, изменение в финансировании театрального зрелища) и др.

Если древнегреческий театр был частью института образования, то начиная с эллинистического периода ситуация начала меняться. Античная драма и театр оказались

(...) на пути становления академических традиций, практикуемых в читальных залах, тема для эрудированных споров и занятий в школах, академиях и университетах, далеких от публичной сцены; это включало контекст, совершенно отличный от традиционного, существовавшего между актерами и зрителями ${ }^{20}$.

Когда принципы проповеди окончательно сложатся, еe основной задачей станет наставление как укрепление в правильности понимания должного, то есть то, что христианские наставники так настойчиво хотели видеть не в театре, а в церкви.

18 М.А. Полякова, Педагогика сцены и театрализация школы: две стороны образовательного процесса, „Нуроthekai” 2018, № 2, с. 169.

19 W. Puchner, op. cit., p. 16.

${ }^{20}$ Ibidem, p. 18. 


\section{Литература}

Burton P., Language in the Confessions of Augustine, New York 2007.

Leyerle B., John Chrysostom's view on the theater, in Theatrical Shows and Ascetic Lives: John Chrysostom's Attack on Spiritual Marriage, Berkeley 2001, p. 42-74.

Lieber L.S., Setting the Stage: The Theatricality of Jewish Aramaic Poetry from Late Antiquity, "The Jewish Quarterly Review" 2014, Vol. 104(4), p. 537-572.

Puchner W., Greek Theatre Between Antiquity and Independence: A History of Reinvention from the Third Century b. c. to 1830, Cambridge 2017.

Revermann M., Introduction, in Cultural History and the Theatres of Antiquity, London-New York 2017.

White A.W., The Artifice of Eternity: A Study of Liturgical and Theatrical Practices in Byzantinum: Ph.D. diss., University of Maryland, 2006.

Аристофан, Лягушки, [в:] Комедии. Фрагменты, Москва 2008, с. 615-705.

Блаженный Августин, Творения в 4 m. Т.з. О Граде Божием. Книги IXIII, Санкт-Петербург - Киев 1998.

Иосиф Флавий, Иудейские древности. Т.2. Кн.13-20. О древности иудейского народа (Против Апиона), Москва 2002.

Лурье, 3.А. Лютеранская проповедь и драматургия: опыт типологических параллелей, „Религия. Церковь. Общество” 2015, № 4, c. 180-187.

Марка Фабия Квинтилиана двенадцать книг Риторических наставлений, часть I, Санкт-Петербург 1834, http://ancientrome. $\mathrm{ru} /$ antlitr/t.htm?a=1327752826.

Пичугина В.К., Школа на сцене: уроки греческого театра $V$ в. до н.э., [в:] Исторические пути развития образования и педагогики, Москва 2015, с. 71-77.

Полякова М.А., Педагогика сцены и театрализация школы: две стороны образовательного процесса, „Нуроthekai” 2018, № 2, c. $163-173$.

Теренций, Евнух, [в:] Комедии, Москва 1985, с. 191-278.

\section{References}

Aristofan, Lâguški, [v:] Komedii. Fragmenty, Moskva 2008, s. 615-705. Blažennyj Avgustin, Tvoreniâ v 4t. T.3. O Grade Božiem. Knigi I - XIII, SanktPeterburg - Kiev 1998.

Burton P., Language in the Confessions of Augustine, New York 2007.

Iosif Flavij, Iudejskie drevnosti. T.2. Kn.13-20. O drevnosti iudejskogo naroda (Protiv Apiona), Moskva 2002.

Leyerle B., John Chrysostom's view on the theater, in Theatrical Shows and Ascetic Lives: John Chrysostom's Attack on Spiritual Marriage, Berkeley 2001, p. 42-74. 
Lieber L.S., Setting the Stage: The Theatricality of Jewish Aramaic Poetry from Late Antiquity, "The Jewish Quarterly Review" 2014, Vol. 104(4), p. 537-572.

Lur'e, Z.A. Lûteranskâ̂ propoved' i dramaturgiâ: opyt tipologičeskih parallelej, „Religiâ. Cerkov'. Obŝestvo” 2015, № 4, s. 180-187.

Marka Fabiâ Kvintiliana dvenadcat' knig Ritoričeskih nastavlenij, čast' I, Sankt-Peterburg 1834, http://ancientrome.ru/antlitr/t.htm?a= 1327752826.

Pičugina V.K., Škola na scene: uroki grečeskogo teatra $V$ v. do n.è., [v:] Istoričeskie puti razvitiâ obrazovaniâ i pedagogiki, Moskva 2015, S. 71-77.

Polâkova M.A., Pedagogika sceny $i$ teatralizaciâ školy: dve storony obrazovatel'nogo processa, „Hypothekai” 2018, № 2, s.163-173.

Puchner W., Greek Theatre Between Antiquity and Independence: A History of Reinvention from the Third Century b. c. to 1830, Cambridge 2017.

Revermann M., Introduction, in Cultural History and the Theatres of Antiquity, London-New York 2017.

Terencij, Evnuh, [v:] Komedii, Moskva 1985, s. 191-278.

White A.W., The Artifice of Eternity: A Study of Liturgical and Theatrical Practices in Byzantinum: Ph.D. diss., University of Maryland, 2006. 